\title{
UJI VALIDITAS KONSTRAK TES MINAT INDONESIA MELALUI ASPEK MINAT PSIKIS
}

\section{CONSTRUCT VALIDITY OF INDONESIA INTEREST TEST WITH IT'S PSYCHOLOGICAL INTERESTS}

\author{
Oleh: \\ Jelpa Periantalo*)
}

\begin{abstract}
ABSTRAK
Tes Minat Indonesia (TMI) berbasis budaya Indonesia yang didasarkan atas minat program studi di perguruan tinggi.Penelitian sebelumnya memberikan dukungan validitas konstrak melalui kelompok minat ilmu kesehatan.Penelitian bertujuan melakukan uji validasi konstrak melalui kelompok minat psikis. Minat Psikis terdiri dari minat Psikologi, Teologi, Filsafat, Komunikasi, Manajemen, Anak Usia Dini dan Anak Berkebutuhan Khusus. Validitas konstrak didapat melalui uji teknik konvergen, divergen, diskriminan dan kelompok.Subjek penelitian berasal dari siswa SMP, SMA, mahasiswa maupun umum. Validitas konvergen adanya hubungan positif minat bidang psikis dengan minat Ilmu Sosial Humaniora ( $r_{x y} 0,453, p=0,000, N=388$ ). Validitas divergen adanya hubungan negatif minat bidang psikis dengan minat Sains dan Teknologi $\left(r_{x y}=-\right.$ $0,450, p=0,000, N=388$ ). Validitas diskriminan tidak ada hubungan minat bidang psikis dengan TPA $\left(r_{x y}=-0,032, \quad p=0,747, \quad N=102\right)$. Validitas kelompok ditunjukkan mahasiswa ilmu psikis memiliki minat $(M=9,33 ; N=76)$ lebih tinggi dari mahasiswa ilmu kesehatan $(M=6,13 ; N=113)$ dengan nilai $t=3,968$; $p=0,000$. TMI dapat digunakan untuk mendiagnosis gambaran minat seseorang untuk pengembangan diri, peminatan SMA maupun penjurusan kuliah.Penelitian berikutnya untuk uji validitas kriteria dengan prestasi belajar, kepuasan belajar serta lama studi.
\end{abstract}

Kata kunci : Diskriminan, Divergen, Konstrak, Konvergen, Minat, Validitas

\section{ABSTRACT}

Indonesia Interest Test based on Indonesian culture from university majoring. It had construct validity from its aspect of health science interests. Purpose of research was to examine construct validity of Indonesia Interest Test through its psychological aspect interests. It consisted of interest in psychology, theology, philosophy, management, communication, early childhood education and special need children. IIT used question with answers and ranking for scaling method. Subjects of research were high school students, university students, and public. Construct validity examined with convergent, divergent, discriminant and group validity. There was a positive correlation psychological interests with social science interest $\left(r_{x y}=.453 ; p=.000 ; N=388\right)$ for convergent validity.

*) Dosen Program Studi Psikologi - Universitas Jambi 
There was a negative correlation between psychological interests with science technology interest $(r=-.450 ; p=.000 ; N=388)$ for divergent validity. There was no correlation psychological interests with academic potential test ( $r=-.032$; $p=.747 ; N=102)$ for discriminant validity. Psycho students had higher score in psycho interest $(M=9,33 ; N=76)$ than health students $(M=6,13 ; N=113)$ for group validity. IIT can be used to diagnosis students' interest for self development, high school majoring and university majoring. Next research examined criterion validity through academic achievement, learning satisfaction and length of study.

KEYWORDS: Construct, Convergent, Discriminant, Divergent Interest, validity

\section{PENDAHULUAN}

Minat merupakan kecenderungan dalam menyukai suatu kegiatan, topik atau benda tertentu (Periantalo, 2014).Minat menimbulkan motivasi internal bagi individu dalam mengerjakan sesuatu.Individu yang mengerjakan sesuatu berdasarkan minat cenderung bersemangat dalam mengerjakan aktivitas tersebut. Minat dapat menimbulkan rasa puas terhadap individu tersebut sehingga mementingkan proses daripada hasil akhir melakukan sesuatu.

Salah satu hal yang penting dalam konstrak psikologi adalah bagaimana cara mengungkap aspek psikologis tersebut (Azwar, 2013). Ada berbagai metode yang dilakukan dalam pengungkapan aspek psikologis, yaitu: observasi, wawancara, tes maupun dokumen. Setiap metode memiliki kelebihan dan kekurangan masing-masing.Bahkan, dalam mencapai keakuratan yang tinggi dilalukan melalui berbagai metode (Periantalo, 2015). Tes merupakan metode yang paling banyak dan sering digunakan.Kelebihan metode ini dapat dilakukan melalui subjek yang banyak serta propertis psikometris dapat dipertanggujawabkan.

Ada berbagai persyaratan terhadap alat ukur psikologi yang baik (Azwar, 2013; Hadjam, 2010; Periantalo, 2015; Seniati, Yulianto, Setiadi, 2010; Widhiarso, 2010). Setiap ahli memiliki kriteria tertentu dalam melihat alat ukur yang baik.Namun, hal yang disetujui oleh para ahli tersebut adalah validitas merupakan syarat utama alat ukur yang baik.Validitas mengacu kepada seberapa akurat alat ukur mampu mengungkap aspek yang hendak diungkap.Apakah aitem yang berada di dalam alat ukur tersebut mengungkap aspek yang harus diungkap.Ia tidak mengungkap aspek yang lain diluar tujuan ukurnya. Jika alat ukur mampu menunjukkan validitas yang baik, alat ukur tersebut memiliki keakuratan yang tinggi dalam melihat potret seseorang secara psikis.

Periantalo (2014) melakukan uji validitas Tes Minat Indonesia dengan sampel terbatas serta menunjukkan hasil yang memuaskan.Validitas konvergen, diskriminan, divergen dan kelompok menunjukkan hasil yang signifikan.Saran 
dari penelitian tersebut adalah melakukan validitas dengan jumlah subjek yang lebih besar sebagai wujud konsistensi validitas. Periantalo dkk (2015) melakukan uji validitas konstrak dengan menguji korelasi minat bidang kesehatan dengan berbagai konstrak yang lain. Validitas konvergen diperlihatkan adanya korelasi positif antara minat kesehatan dengan minat sains teknologi.Validitas divergen diperlihatkannya ada korelasi negatif antara minat kesehatan dengan minat psikis.Validitas diksriminan ditunjukkan tidak ada korelasi antara minat kesehatan dengan sikap terhadap pelajaran Sosial Humaniora.Validitas kelompok ditunjukkan dengan mahasiswa Kedokteran memiliki minat yang tinggi pada bidang Kesehatan.

Ada berbagai manfaat dari Tes Minat Indonesia baik akademisi maupun praktisi. Manfaat akademis dapat digunakan sebagai bahan perkuliahaan, instrumen penelitian maupun uji validitas kriteria terhadap alat ukur tertentu. Psikolog professional dapat menggunakan tes minat ini dalam praktik psikologi.Ia dapat memberikan gambaran pengembangan minat bakat, peminatan sekolah, penjurusan kuliah, seleksi karyawan dan bahkan pengembangan karier karyawan. Adapun komponen minat ilmu psikis dalam tes minat Indonesia bisa dilihat dalam tabel berikut :

Tabel 1. Komponen Minat Psikis - Tes Minat Indonesia

\begin{tabular}{|c|c|}
\hline Komponen & Definisi \\
\hline FILSAFAT & $\begin{array}{l}\text { menyenangi esensi dari manusia, kehidupan, tuhan, dan alam semesta yang tecermin } \\
\text { pada kegiatan: mendiskusikan, mempelajari, merenungkan, menulis, } \\
\text { mempraktikannya, dan membaca buku-buku pemikiran orang hebat. }\end{array}$ \\
\hline TEOLOGI & $\begin{array}{l}\text { menyenangi sesuatu yang berhubungan dengan ajaran keagamaan, ketuhanan, } \\
\text { kepercayaan yang meliputi kegiatan mendiskusikan, mempelajari, } \\
\text { mempraktikannya, membaca, dan menyebarkan kepercayaan } \\
\text { yang dianut. }\end{array}$ \\
\hline PSIKOLOGI & $\begin{array}{l}\text { menyenangi sesuatu yang berhubungan dengan diri pribadi atau Jiwa Manusia, } \\
\text { seperti emosi, jiwa, karakter, kepribadian, motivasi yang tecermin pada } \\
\text { kegiatan:mendiskusikan, mempelajari, mendengarkan, dan mengamati perilaku orang } \\
\text { lain. }\end{array}$ \\
\hline KOMUNIKASI & $\begin{array}{l}\text { menyenangi aktivitas komunikasi massa, menyampaikan informasi di hadapan } \\
\text { khalayak ramai secara lisanryang tercermin pada kegiatan berbicara di depan umum, } \\
\text { menjadi moderator,pembawa acara suatu kegiatan atau juru bicara } \\
\text { menvenangi sesuatu vang berhubungan dengan dunia anak tercermin nada kegiatan: }\end{array}$ \\
\hline DUNIA ANAK & $\begin{array}{l}\text { menyenangi sesuatu yang berhubungan dengan dunia anak, tercermin pada kegiatan: } \\
\text { bermain, berdiskusi, mengasuh,mengajarkan sesuatu, mengoptimalkan potensinya, } \\
\text { serta kampanye kepeduliannya. }\end{array}$ \\
\hline ANAK & menyenangi Anak Berketubuhan Khusus, seperti autis, retardasi mental, hiperaktif, \\
\hline $\begin{array}{l}\text { 3ERKEBUTU } \\
\text { HAN KHUSUS }\end{array}$ & $\begin{array}{l}\text { downsyndrome, tunanetra baik itu meliputi berdiskusi, mempelajari, mengasuh, } \\
\text { maupun berkampanye }\end{array}$ \\
\hline & \\
\hline PENDIDIKAN & $\begin{array}{l}\text { menyenangi sesuatu yang berhubungan dengan dunia pendidikan, seperti strategi } \\
\text { belajar, semangat belajar, dan peningkatan kualitas pendidikan yang meliputi } \\
\text { kegiatan: senang berdiskusi, mengajar, maupun kampanye kepedulian pendidikan. } \\
\text { menyenangi sesuatu yang berhubungan dengan manajemen, tercermin pada kegiatan: }\end{array}$ \\
\hline MANAJ & $\begin{array}{l}\text { membuat mengevaluasi sebuah perencanaan, terlibat aktif dalam organisasi, serta } \\
\text { menyenangi sesuatu berhubungan dengan kepemimpinan }\end{array}$ \\
\hline
\end{tabular}


Berdasarkan uraian tersebut, maka tujuan penelitian ini adalah melakukan uji validitas konstrak Tes Minat Indonesia melalui kelompok minat bidang Psikis.Validitas konstrak didapat melalui validitas konvergen, divergen, diskriminan dan kelompok.Validitas konvergen diuji antara minat psikis dengan minat ilmu sosial humaniora.Kedua konstrak ini berkorelasi positif karena merupakan hal yang saling berhubungan.Validitas divergen didapat dengan uji korelasi minat psikis dengan minat ilmu alam. Kedua konstrak tersebut merupakan hal yang berlawanan, hasil korelasi idealnya menunjukkan korelasi negatif.Validitas diskriminan didapat melalui uji korelasi minat psikis dengan Tes Potensi Akademik. Kedua konstrak tersebut tidak berhubungan dengan idealnya tidak berkorelasi.Validitas kelompok didapatkan melalui nilai rata-rata minat terhadap Psikis pada mahasiswa Psikologi/Bimbingan Konseling dengan mahasiswa Ilmu Kesehatan.

\section{METODE}

\section{Instrumen Penelitian}

Instrumen yang digunakan dalam penelitian ini adalah Tes Minat Indonesia (Periantalo, 2014).Tes ini terdiri dari 99 pilihan jawaban yang mengambarkan 99 aspek minat. Terdapat 9 minat Psikis yang berada dalam kelompok minat tersebut. Tes minat ini sudah melalui uji propertis psikometris awal yang memuaskan (Periantalo, 2014).Tes Potensi Akademik (TPA) digunakan sebagai uji validitas diskriminan, TPA tersebut sudah disusun oleh peneliti dan didukung oleh validitas konvergen (Periantalo, 2014).

\section{Metode Pegumpulan Data}

Data yang digunakan dalam penelitian berasal dari tes psikologi yang dilakukan oleh peneliti dan kelas yang peneliti ampu.Data berasal dari tes seleksi masuk SMA, peminatan sekolah, penjurusan kuliah, seleksi mahasiswa baru serta seleksi tenaga kerja.

\section{Model Penskalaan}

Model penskalaan yang digunakan dalam penelitian berupa pertanyaan dengan beberapa pilihan jawaban dan ranking. Subjek diminta untuk memilih 7 dari 99 pilihan jawaban yang tersedia.Kemudian, subjek diminta untuk merangking pilihan tersebut.Ranking nomor 1 merupakan minat yang paling disenangi dan memiliki skor 7.Ranking nomor 2 merupakan minat nomor dua yang disenangi dan memiliki skor 6.Ranking nomor 3 merupakan minat nomor tiga yang disenangi dan memiliki skor 5.Ranking nomor 7 merupakan minat nomor tujuh yang disenangi dan memiliki skor 1.Untuk pilihan yang tidak dipilih, tidak diberi skor.

\section{Subjek}

Subjek dari penelitian berasal dari berbagai kalangan, yaitu: siswa SMP, siswa SMA, mahasiswa dan umum. Siswa berasal dari berbagai SMP dari setiap kabupaten di dalam Propinsi Jambi. Siswa SMA berasal dari beberapa sekolah. 
Mahasiswa berasal dari Program Studi Pendidikan Dokter, Ilmu Keperawatan, Ilmu Kesehatan Masyarakat, Psikologi dan Bimbingan Konseling.

\section{Metode Analisis Data}

Terdapat dua metode analisis data dalam penelitian ini, yaitu: korelasi dan uji beda. Korelasi bertujuan untuk melihat hubungan dua variabel atau lebih.Korelasi digunakan untuk uji validitas konvergen, divergen dan diskriminan.Teknik korelasi yang digunakan adalah Pearson Product Moment. Berkoreasi atau tidaknya konstrak yang diuji dengan menggunakan nilai signifikansi sebesar LOS 0,01 . Sementara uji $t$ test independent sample digunakan dalam uji validitas kelompok. Untuk melihat perbedaan di antara dua kelompok yang dibandingkan.

\section{HASIL DAN PEMBAHASAN}

\section{Validitas Konvergen}

Uji validitas konvergen dilakukan antara kelompok minat psikis dengan kelompok minat sosial humaniora.Kelompok minat psikis merupakan bagian dari kelompok minat sosial humaniora. Kedua jenis variabel mengungkap hal yang relatif sama,hasil uji korelasi harus menunjukkan adanya korelasi positif antara kedua variabel ini. Tinggi skor suatu variabel menunjukkan tingginya skor pada variabel yang lain,rendahnya skor suatu variabel menunjukkan rendahnya skor pada variabel yang lain.

Tabel 2. Hasil Korelasi Minat Psikis dengan Sosial Humaniora

\begin{tabular}{cc}
\hline & Minat Ilmu Sosial \\
\hline Minat Psikis & $\mathrm{r}=0,453$ \\
& $\mathrm{p}=0,000$ \\
$\mathrm{~N}=388$ \\
\hline
\end{tabular}

Uji korelasi antara kedua variabel tersebut melibatkan sebanyak 388 subjek dengan koefiisen korelasi $\mathrm{r}_{\mathrm{xy}}$ 0,453 dengan nilai signifikansi 0,000 .Uji korelasi menunjukan adanya korelasi positif sedang antara kelompok minat bidang psikis dengan kelompok minat sosial humaniora. Subjek yang memiliki skor yang tinggi pada bidang psikis, ia memiliki skor yang tinggi pula pada sosial humaniora. Subjek yang memiliki skor yang rendah pada bidang psikis, ia memiliki skor yang rendah pula pada bidang sosial humaniora. Data tersebut memberikan dukungan terhadap validitas konvergen Tes Minat Indonesia melalui kelompok bidang psikis.

\section{Validitas Divergen}

Uji validitas divergen dilakukan antara minat bidang psikis dengan kelompok minat sains teknologi.Bidang psikis merupakan kelompok minat sosial humaniora, sementara minat sains teknologi merupakan lawan dari kelompok minat sosial humaniora.Jika kedua variabel tersebut diuji korelasi idealnya 
menghasilkan korelasi negatif. Besarnya nilai suatu variabel menunjukkan rendahnya variabel yang lain,rendahnya suatu variabel menunjukkan tinggi variabel yang lain.

Tabel 3 Hasil Uji Korelasi Minat Psikis dengan Minat Sains Teknologi

\begin{tabular}{cc}
\hline & Minat Sains Teknologi \\
\hline Minat Psikis & $\mathrm{r}=-0,450$ \\
& $\mathrm{p}=0,000$ \\
& $\mathrm{~N}=388$ \\
\hline
\end{tabular}

Uji korelasi menunjukkan adanya korelasi negatif sedang antara minat bidang psikis dengan minat bidang sains teknologi.Uji tersebut dengan melihatbakn 388 subjek, dengan koefisien korelasi sebesar rxy -0,450 dengan nilai signifikansi sebesar 0,000.Bidang minat sains teknologi seperti: medis, elektrik, pertambangan, planologi, kehutanan. Subjek yang memiliki minat yang tinggi pada bidang psikis, ia memiliki ilmu sains teknologi yang rendah. Subjek yang memiliki minat yang rendah pada bidang psikis, ia memiliki minat sains teknologi yang tinggi. Apa yang telah diasumsikan terbukti bahwa kedua variabel tersebut menghasilkan korelasi negatif.

\section{Validitas Diksriminan}

Uji validitas diksriminan dilakukan antara minat bidang psikis dengan Tes Potensi Akademik.Minat dan tes potensi merupakan hal yang berbeda.Minat merupakan komponen afektif, sementara tes potensi merupakan komponen kognitif.Begitu juga dengan komponen yang membentuk kedua konstrak tersebut.Jika kedua variabel atau konstrak tersebut dikorelasikan, hasil korelasi menunjukkan tidak adanya korelasi.

Tabel 4 Hasil Korelasi Minat Psikis dengan Tes Potensi Akademik

\begin{tabular}{cc}
\hline & Tes Potensi Akademik \\
\hline Minat Ilmu Psikis & $\mathrm{r}=-0,032$ \\
& $\mathrm{p}=0,747$ \\
$\mathrm{~N}=102$ \\
\hline
\end{tabular}

Uji korelasi menghasilkan koefisien korelasi sebesar -0,032 dengan nilai signifikansi ditetapkan sebesar 0,01 serta melibatkan 102 subjek. Kedua variabel tersebut tidak berkolerasi karena di atas standar yang ditetapkan.Uji validitas menunjukkan tidak adanya korelasi antara minat bidang psikis dengan tes potensi akademik.Tinggi-rendahnya minat siswa pada bidang psikis tidak dapat ditentukan melalui hasil Tes Potensi Akademiknya.Begitu juga sebaliknya, tinggirendahnya nilai TPA seseorang, tidak dapat diketahui apakah minat psikis rendah, sedang atau tinggi.Apa yang dihipotesiskan terbukti bahwa tidak hubungan di antara dua konstrak tersebut. 


\section{Validitas Kelompok}

Validitas kelompok mengkonfirmasi alat ukur dengan kelompok tertentu.Kelompok yang idealnya memiliki karakteristik tertentu dapat dibuktikan melalui alat ukur.Kelompok tersebut memiliki skor yang tinggi dengan kelompok yang tidak/kurang memiliki karakteristik tersebut.Uji validitas kelompok dilakukan kepada mahasiswa Psikologi dan Bimbingan Konseling.Dua jurusan ini mempelajari sesuatu yang berhubungan dengan psikis. Sebagai pembanding, kelompok jurusan ilmu ilmu kesehatan, yaitu: Pendidikan Dokter, Ilmu Keperawatan dan Ilmu Kesehatan Masyarakat.

Tabel 5 Nilai uji t test independent sample

\begin{tabular}{lccccc}
\hline \multicolumn{1}{c}{ Jurusan } & N & M & SD & t & p \\
\cline { 1 - 4 } Kelompok Ilmu Psikis & 76 & 9,46 & 6.596 & 3,968 & 0,000 \\
\cline { 1 - 4 } Kelompok Ilmu Kesehatan & 113 & 6,13 & 4.992 & & \\
\hline
\end{tabular}

Data menunjukkan bahwa mahasiswa kelompok Psikis memiliki minat yang lebih tinggi pada ilmu psikis dari mahasiswa ilmu kesehatan. Mahasiswa ilmu Psikis memiliki skor sebesar $\mathrm{M}=9,33$; mahasiswa kesehatan sebesar $\mathrm{M}=6,13$. Bila dilihat dengan uji t independent sample didapat nilai t sebesar 3,968 dan signifikansi sebesar 0,000.Nilai signifikansi tersebut dibawah standar yang ditetapkan sehingga berbeda kedua kelompok tersebut.Apa yang dihipotesikan terbukti bahwa mahasiswa kelompok ilmu psikis memiliki minat yang tinggi dari kelompok ilmu kesehatan.

\section{KESIMPULAN}

Apa yang diasumsikan pada awal penelitian terbukti sehingga memberikan validitas konstrak pada Tes Minat Indonesia melalui aspek ilmu Psikis. Terdapat korelasi positif minat Psikis terhadap minat Sosial Humaniora.Kedua konstrak tersebut merupakan hal yang saling berhubungan sehingga validitas konvergen dapat ditegakkan.Terdapat korelasi negatif minat Psikis terhadap minat Sains Teknologi.Kedua konstrak tersebut merupakan hal yang berlawanan sehingga validitas divergen dapat ditegakkan.Tidak terdapat korelasi antara minat Psikis dengan Tes Potensi Akademik.Kedua konstrak tersebut merupakan hal yang berbeda sehingga validitas diskriminan dapat ditegakkan.Mahasiswa Ilmu Psikis memiliki skor minat Psikis lebih tinggi dari Mahasiswa Ilmu Kesehatan sehingga memberikan dukungan validitas kelompok.Untuk mencapai validitas yang baik, penelitian berikutnya disarankan untuk melakukan uji validitas kriteria baik secara konkuren maupun prediktif.Uji validitas melibatkan kriteria keberhasilan belajar melalui prestasi akademik, kepuasan belajar dan lama studi.

\section{DAFTAR PUSTAKA}

Azwar, S. (2011). Dasar-dasar psikometri. Yogyakarta: Pustaka Pelajar:

Azwar, S. (2013). Metode penelitian. Yogyakarta: Pustaka Pelajar. 
Azwar, S. (2013). Reliabilitas dan validitas. Yogyakarta: Pustaka Pelaja.

Azwar, S. (2014). Sikap manusia: teori dan pengukurannya. Yogyakarta: Pustaka Pelaja.

Azwar, S. (2014). Penyusunan skala psikologi. Yogyakarta: Pustaka Pelaja..

Hadjam, N. (2010). Penerapan hasil tes psikologi pada layanan bimbingan konseling. Diunduh dari http://wahyupsy.blog.ugm.ac.id/.

Manap, et.al.(2013). Prinsip Pengukuran Religiositi dan Personaliti Muslim. Journal of Psychology and Human Development, 1 (1), 36 - 43.

Periantalo, J. (2011). Laporan praktek kerja profesi psikologi tingkat SMP di SLTPN 5 Yogyakarta (Tidak Dipublikasikan). Fakultas Psikologi Universitas Gadjah Mada, Yogyakarta.

Periantalo, J. (2011). Laporan praktek kerja profesi psikologi tingkat SMAN 9 Yogyakarta (Tidak Dipublikasikan). Fakultas Psikologi Universitas Gadjah Mada, Yogayakarta.

Periantalo, J. (2012). Konstuksi optima personality scaledari tipologi kepribadian Jung dan Myers-Briggs. (Tesis Tidak Dipublikasikan). Fakultas Psikologi Universitas Gadjah Mada, Yogyakarta.

Periantalo, J. (2014, Desember). Penyusunan tes minat Indonesia sebagai upaya pengembangan diri generasi muda Indonesia. Presented at Temu Ilmian Nasional 2014 Fakultas Psikologi Universitas Airlangga, Surabaya.

Periantalo, J., Fadzlul., Saputra, N. E., Saputra. (2014). Konstruksi skala sikap terhadap pelajaran Matematika dan Sains. Jurnal Edu Sains Universitas Jambi 3 (2) 36-45.

Periantalo, J. (2015). Penyusunan skala psikologi:asyk, mudah dan bermanfaat. Yogyakarta: Pustaka Pelajar.

Periantalo, J. (2015). Validitas alat ukur psikologi: Aplikasi praktis.Yogyakarta: Pustaka Pelajar.

Periantalo, J. (2016). Penelitian kuantitatif untuk Psikologi.Yogyakarta: Pustaka Pelajar.

Periantalo, J. (2017). Statistika dasar untuk Psikologi. Yogyakarta: Pustaka Pelajar.

Seniati, L., Yulianto, A., \& Setiadi, B. N. (2011).Psikologi eskperimen. Jakarta: Indeks.

Suharsono, Y., \& Istiqomah. (2014). Validitas dan Reliabilitas Skala Self Efficacy. Jurnal Ilmiah Psikologi Terapan Universitas UMM, 02 (01), 144-151.

Supratiknya, A. (2014). Pengukuran psikologis. Yogyakarta: Penerbit Universitas Sanata Darma.

Widhiarso, W. (2010). Dimensionalitas skala. Diunduh dari http://wahyupsy.blog.ugm.ac.id/. 
JELPA PERIANTALO, Uji Validitas Konstrak Tes Minat Indonesiamelalui Aspek Minat Psikis

Widhiarso, W. (2010). Konstrak psikologis. Diunduh dari http://wahyupsy.blog.ugm.ac.id/.

Widhiarso, W. (2010). Validitas isi. Diundur dari http://wahyupsy.blog.ugm.ac.id/.

Widhiarso, W. (2010). Validitas Konstrak. Diunduh dari http://wahyupsy.blog.ugm.ac.id/.

Widhiarso, W. (2010). Validitas kriteria. Diunduh dari http://wahyupsy.blog.ugm.ac.id/. 